\title{
Inclusive Women's Organisations in Denmark and Norway?
}

\section{By Helene Pristed Nielsen}

\section{and Cecilie Thun}

Should Danish and Norwegian feminists make special efforts to collaborate with ethnic minority women to promote women's interests across ethnic differences? This is a troublesome question in both tone and words. Who defines who is 'Norwegian', 'Danish', 'feminist', 'ethnic minority woman', what 'ethnic differences' and which 'interests'? Inspired by Phillips' (2007) point about feminist scholars becoming "prone to paralysis by cultural difference", we approach the question at the intersection of feminism and ethnicity, yfocusing on how 'majority' women's organizations in Denmark and Norway respond to ethnic 'minority' women in their countries?

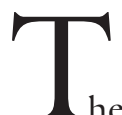

he article springs from two studies, one of the mobilization of Muslim women in Denmark, and another of the relationship between majority and minority women's organizations in Norway. ${ }^{2}$ Data collection was coordinated because we suspected there might be interesting comparative conclusions to draw regarding how majority organizations in Denmark and Norway respond to the increasing number of women with ethnic minority background in both countries. Dogan and Pelassy write about binary comparisons that they are "often used for countries that show contextual similarities, even if the aim of the analysis is to bring out differences in one or more specific fields" (1990: 127). The focus on women's organizations is particularly interesting considering these two countries' reputations as having obtained a high degree of gender equality. ${ }^{3}$

The focus is empirical (how do the organizations respond?), and our theoretical ap- 
proach is informed by Phillips (2007) and Bacchi (2009). Inspired by Bacchi's 'what's the problem represented to be?' (WPR) approach, we probe conceptual underpinnings of problem representations among respondents within majority women's organizations and discuss their possible effects. 'Problem representations' is understood as competing understandings of social issues (Bacchi 1999: 5). This is why we consider WPR appropriate for analyzing interview data, and not only for policy analyses, which is how Bacchi applies the method.

Bacchi speaks of common characteristics of problem representations as 'presuppositions' (2009: 4-10). Several pieces of previous academic work argue for some commonality of 'presuppositions' in Denmark and Norway. Langvasbråten states that "a high-profiled ideal of gender equality has certainly been an important ingredient in the construction of a homogenous 'Scandinavianness" (2008: 33). And Siim's and Skjeie's exploration of differences in policy responses to the presence of migrant women in Denmark and Norway is based on "a strong state feminist tradition in both countries" (2008: 323). In both countries, Siim and Skjeie identify a "'gender equality paradox', which refers to the simultaneous inclusion of women from ethnic majority backgrounds and exclusion of women from ethnic minority backgrounds in core political institutions such as parliament and government" (Siim and Skjeie 2008: 339). In Bacchi's terminology, presuppositions seem similar. ${ }^{4}$

Phillips' point about feminist scholars becoming "prone to paralysis by cultural difference" (2007: 1) prompts us to ask the question of responsibility versus hands-off regarding the relationship between 'old' feminist organizations and those of immigrant women. We probe whether paralysis has spread to women's organizations, possibly "engendering a kind of relativism that [has] made it difficult to present any belief or practice as oppressive to women or at odds with gender equality" (Phillips 2007: 1). We apply the metaphor of Scylla and Charybdis to situations in which majority women's organizations may be caught between paternalism and paralysis, as we explore how respondents within them talk about collaboration efforts and experiences (or lack thereof) with minority women's organizations.

Our aim is to explore the understandings and meaning-making in qualitative interviews with core members in majority women's organizations concerning whether and how to collaborate with ethnic minority women. This serves a dual purpose: firstly, probing the underlying presuppositions of problem representations as put forward in the interviews; secondly, drawing conclusions about the effects of these problem representations. "We need to direct attention to the effects that accompany specific problem representations" (Bacchi 2009: 15). Bacchi mentions three types of potential effects of problem representations: 1) discursive effects (impacts on what can/cannot be said);2) subjectification effects (the ways in which subjects are constituted in discourse); and 3 ) lived effects (material consequences) (2009: 15-18). These distinctions will be applied in our analysis.

\section{EMPERICAL MATERIAL}

Data from Norway consists of 24 interviews; 19 with activists from 14 different women's organizations and five with civil servants and politicians. ${ }^{5}$ The selection of Norwegian organizations was based on a mapping of the contemporary women's movement (Eggebø et al. 20076). In Denmark, 33 interviews with a total of 43 persons were conducted (some as group interviews). ${ }^{7}$ Out of these, eight were civil servants or employed by majority organizations in liaison functions. Our focus is the majority organizations, and the quotes presented are from interviews with representa- 
tives from these. ${ }^{8}$ Due to the selection criteria there is a bias in the data analyzed below because Danish data has been collected among people already collaborating. Due to a lack of large national immigrant women's associations in Denmark at the time of interviewing, organizations were searched for in three larger municipalities: Copenhagen, Aarhus and Aalborg. Less traditional types of organizations such as housing estates running collaborative projects were included.

Thus, the two studies differ in their design, both regarding the focus on several geographic locations in Denmark and the more homogenous nature of the Norwegian organizations in the sample. The Danish study included interviews with two respondents from the Women's Council of Denmark as well as a handful of people in liaison functions within majority organizations. However, there are also commonalities in the research designs: they are based on a qualitative approach to research and in-depth interviews with partly coordinated topic guides. Interviews were conducted in Norway between May 2007 and May 2008, and in Denmark between August 2007 and January 2008.

Our analysis is based on an inductive approach and thus grounded in data. Although not using 'grounded theory' in Strauss and Corbin's (1998) sense where themes for analysis spring from data itself (having already selected 'collaboration' as the main theme), we were looking for commonalities and differences between and within the data sets, applying an 'open coding' technique for tracing issues - albeit on an already delimited part of the data. Originally focusing on interviews with both majority and minority respondents, it was soon clear that statements by majority respondents would be interesting to discuss in light of Phillips' (2007) crux regarding the inclusion of minority women in the existing women's movement. When it comes to whether and how to collaborate with minority women and their organizations, certain issues appear in different guises in statements from both national settings. The coding process pointed towards at least three different elements of the 'problem' being represented, elements that can be described as organizational, cultural and attitudinal assumptions underlying the problem representations.

\section{ORgANIZATIONAL ASSUMPTIONS}

The following statement from Norway illustrates how organizational assumptions might impede collaboration:

“They [minority women's organizations] might perceive us as dominating; that we want to be in charge and so forth. We haven't been able to present ourselves as open-minded. And then you have all these different organizations which mean very different things. In general there are few organizations only for women."

The many different minority organizations with different foci are partly viewed as responsible for making collaboration a confusing task. The underlying assumption in several interviews is that minority women organize primarily as 'ethnic minorities', and common interests as 'women' are downplayed. The intersection between discrimination based on gender and ethnicity is seldom present in the Norwegian interviews with majority women. The financial support schemes in Norway clearly indicate separate spheres of 'women's issues' and 'minority issues', 9 and the organizational landscape mirrors this assumption. The idea that organizational assumptions may be standing in the way of collaboration between majority and minority women in Norway is supported also in a historical perspective by Salimi (2004). In Norway, minority women started to organize at the end of the 1970s. The Foreign Women's Group (FWG, est. 1979, later MiRA cen- 
tre) was a pioneer. According to Salimi, the FWG wanted to establish a broader platform from which to obtain 'sister solidarity' with majority Norwegian women, but the white women's movement did not acknowledge racist gender discrimination, and did not recognise its own role in making the issue invisible. ${ }^{10}$

In Denmark, majority organizations often obtain funding directly from government coffers for their special 'ethnic' efforts, which makes Bacchi's point about presuppositions pertinent for interpreting interview statements. An example of how majority respondents almost literally had to fight off underlying assumptions immanent in the dominant political discourse can be seen in the two following statements:

"The idea was to use the knowledge [our organization] has concerning organizational work; use it to support foreign women in Denmark. [...] the idea was to like help women to - well, not 'help', it sounds so ... but then support women via organizational life to be active in society."

Interviewer: "You coordinate some activities from here $[\ldots]$, but how about the women, do they also coordinate things themselves, or is it more on your initiative?"

Respondent: "What we wish to do is to anchor it, $[. .$.$] but exactly with an eye to seeing$ that it is solidly grounded, so that others in the area take over and we make ourselves superfluous somehow. But it is a mega long process and it is really difficult [original emphasis]."

Using words like 'support' and 'anchor' rather than 'help', which is rejected as an adequate expression, these respondents signal a reluctance to buy into the underlying assumption that gender equality and female emancipation is something 'they' should learn from 'us'. Nevertheless, the latter respondent did use rather interventionist strategies to obtain her goal of making her organization superfluous in securing a thriving local organizational landscape that would also include minority women's interests:

“... something like a general assembly; there we take them from their aerobics class, we get to use the last quarter of an hour. We stop the class; "go down to our rooms and vote". And in this way they find out that at this meeting they can stand up and say "we would like ..." - and they are listened to.”

It seemed an accepted strategy among majority respondents in Denmark to intervene in the organizational processes of minority women's groups, and the majority organizations could easily hold objectives for these groups that might be more relevant than the aims and goals initially expressed by the minority organizations themselves. The subjectification effects of the above mentioned representations differ in interesting ways. The Norwegian respondent is concerned with appearing open-minded and non-dominating, whereas Danish respondents seem happy to take the first steps. Both are examples of a dynamic of 'dividing practices' (Foucault in Bacchi 2009: 16), but in the Norwegian instance also the majority women are subjectified.

\section{Cultural assumptions}

The Norwegian quote opening the analysis continues with the words:

"And they have some issues that they are very concerned with. So we have a very different point of departure. They have other problems. [...] They might think that our problems are 'luxury problems'. Because they have a different background and a different reality [...]."

A common assumption among several interviewees in Norway was that minority 
women have different interests, and that these differences could course difficulties for any collaboration efforts. The discursive effect of this type of argument is that the option of collaboration is closed off. The emphasis on difference is very evident in the interview material, and it is used either to explain the lack of collaboration, or is an underlying assumption throughout the interviews. According to Narayan (1997), phenomena that seem 'different', 'alien' and 'other' cross borders more easily than problems that seem more 'familiar' in a Western context. The 'hypervisibility' in the media of issues like forced marriages and female genital mutilation linked to ethnic 'minorities' (Bredal 2007: 60) might have exaggerated the image of minority women as different.

"I think we have been a bit afraid of putting violence against migrant women on the agenda because one is afraid of doing something wrong and contributing to further stigmatization and discrimination. [...] In relation to honour killing and forced marriages, the political right has been more attentive, rather than the political left and the women's movement. I think that's a pity, both for the women's movement and those who are victims of forced marriages. I think these are extremely difficult issues, of course. [...] I don't think that [my organization] has a well-developed policy on these issues."

This problem representation reflects a dilemma between the recognition of religion and culture and concern about women's subordination in minority cultures. The majority interviewees talk about many 'ditches' to fall into, and to be able to criticize oppression of women within minority communities while at the same time not stigmatizing a whole group, an exercise described as 'balancing on a knife's edge'. The assumption that underlies this problem representation is the fear of playing into a right-wing agenda - the subjectification ef- fects are on the Norwegian majority women as they are the ones having to do the balancing. ${ }^{11}$ The dilemma endangers collaboration with organizations representing minority women making majority organizations prone to paralysis.

Moving on to the Danish data, a typical example is the following interviewee, working for a housing estate, which saw it as being in its own interest to run a club for the (primarily immigrant) women living in the area:

"We focus on the ethnic women to a great extent, and try to strengthen them in their everyday lives and their integration process here in Denmark, and that is obviously based on the fact that women often are the key to the integration of the family."

Hence assuming that the organization of these women would be in the interest of the housing estate itself, and also implying the subjectification effect that minority women somehow hold a special responsibility towards their families. The question of whose best interest is being pursued also comes out in the following:

"Sometimes I worry a lot about the organizations where I come as a consultant and they are very closed. It is my job to make sure that they develop a network [...]. We try to build those bridges, and sometimes I feel - you know, sometimes I am met with "No, we don't want to cooperate with them, because they are a different nationality, and we have nothing in common with them"."

Altogether, the Danish data suggests that attitudes are to be changed and differences to be overcome whether the suggested goal is to 'integrate' or 'develop a network', thus steering well clear of paralysis. However, at the risk of running head-on into paternalistic notions that these women need 'help' to organize themselves, or at least someone to 'support' or 'anchor' 
them. There is a clear 'target group' implied in this type of discourse, although it is less clear who is responsible for the 'problem'.

\section{ATtiTUdes AND RESPONSIBILITIES}

The previous Minister of Integration in Denmark Rikke Hvilshøj (The Liberal Party) has stated that "[Danish society] has not been good enough at expecting the best from these women" (Ministry of Integration 2007: 2). This formulation directs blame at the Danish majority while at the same time expecting action from the minority. However, most majority respondents in Denmark seemed to place both blame and the burden of action primarily on the majority itself.

"We $[\ldots]$ have to become better at - and not least better at remembering that this group of citizens and their organizations also sort under us. We also have to provide services for them. $[\ldots]$ is very much about what you can do as an organization or volunteer centre in regards to being inclusive, rather than ending up being exclusive. [...] Because it often happens, at least within the voluntary sector and, I believe, in many other parts of society that many - without wanting to - end up being exclusive. And not because they have decided that there are some people they do not want include, but they simply have some routines that make it difficult for others to gain access."

Another respondent said that although her office is open to everybody, most people who contacted her for free guidance on anything from how to hire an aerobics instructor to understanding a letter from their children's school were of Danish majority background. Asked why she thought so few minority persons made use of her, she replied:

"Well, I don't think we have worked at it in a very goal oriented fashion $[\ldots]$ and I think that's what it takes. [...] When I started working here, that was actually one of my primary aims, to get a closer dialogue."

Another organization was also promoting dialogue, but not at any price:

"We would like to have more [ethnic Danish volunteers], but it is difficult to find some [...] who don't just show up thinking that they should teach immigrant women how to behave. People who bring all their prejudices along we don't want at all."

Respondents generally indicated that it was the Danish majority, which needed an attitudinal change regarding whether and how to collaborate. This contrasts heavily with the following quote from Norway:

"Solidarity is to lead the way, to show that structural change is possible. [...] So don't say that we have to stop demanding more because Somali or Pakistani women are victims of repression by the family or by imams. [... The reason they are disadvantaged is that they have a different family culture, a different suppression and cultural expectations to how they should live their lives and what choices they can make."

An underlying assumption is that structural problems are the main hindrance for majority women's liberation while oppression of minority women is due to a different family culture. Minority women are not oppressed by Norwegian society as such, but by the culture within their 'ethnic' community. The fight against racism and ethnic discrimination is not included in this representation, thus ignoring the intersections between gender and ethnicity. The representation of minority violence as 'special' and explained by 'minority culture' is in line with much of the media coverage of 'honour killings' in Norway, where this violence is described as 'cultural', whereas cases 
where ethnic Norwegian men kill their wives are called 'family tragedies' (Bredal 2007).

Interestingly, this category shows a reverse tendency compared to the two categories above. The Norwegian respondent in this case seems much more generalizing, although part of the first quote opening up the analysis could be repeated for its similarity with Danish responses: "We haven't been able to present ourselves as openminded." However, applying Bacchi's idea of looking at the effects of problem representations, results do seem consistent along the three analytic categories. The analysis of attitudes and responsibilities also points towards paralysis on the part of Norwegian respondents, as opposed to Danish statements, which consistently indicate actions to be undertaken (or intended to be undertaken), however, at the risk of paternalism.

\section{CONCLUSION}

Most majority respondents in Denmark expressed nuanced views on how and why to collaborate with minority women's organizations, although most conceived collaboration as mainly being in the best interest of minority women. Claiming that Danish respondents are paternalists would not be fair, but based on the available material it is striking that when considering how majority women's organizations in Denmark and Norway respond to ethnic minority women in their countries, we do find interesting differences between the two countries. Placing our analysis in the normative crux between a Scylla of paternalism and a Charybdis of paralysis, we see that Danish and Norwegian majority organizations appear to navigate these dangerous waters in slightly different manners, Norwegian organizations being relatively more prone to paralysis, and Danish organizations more prone to paternalism. This is an interesting conclusion in light of Phillips' (2007) discussion. It should be emphasized, however, that while Ulysses made a choice of which of the two to steer closer to, it is questionable that Danish majority women choose paternalism. The two different responses can also be understood in light of the broader political/organizational context, which we have only briefly mentioned (funding etc.), 12 as well as by the different selection criteria for including organizations.

When we consider the data in light of Bacchi's three types of potential effects of problem representations (discursive, subjectification and lived effects), differences are less significant. In both settings, respondents clearly indicated by their choice of words that salient problem representations by media and politicians sometimes make it difficult for them to express their intentions without buying into a dominant discourse - e.g. the use of 'support' and 'anchor' in the Danish data and the fear of 'falling into ditches' in the Norwegian data. 'Discursive effects' seem similar in both countries.

Concerning subjectification effects, the data presented above, especially under the heading 'cultural assumptions', indicates that some Norwegian respondents saw minority women as 'different' and 'other' whereas Danish respondents to varying degrees indicated that 'we' could be of assistance to 'them'. In both cases there is a tendency to use categories like 'us' and 'them', which Bacchi with reference to Foucault speaks about as 'dividing practices' (2009: 16). The lived effects of these dividing practices are likely to be different, however, as 'difference/otherness' indicates an insurmountable divide and 'assistance' a need for bridging. The most likely longterm 'lived effect' of the problem representations seems to be that organizations within the two countries respond differently to minority women with Danish majority organizations being more prone to assist in organizing minority women while Norwegian organizations seem more hesitant to involve themselves, despite the possibility of a point of contact from an early stage via 


\begin{tabular}{|c|c|c|c|}
\hline Country & Org. name & Org. characteristics & $\begin{array}{l}\text { Ethnic } \\
\text { characteristics }\end{array}$ \\
\hline$\frac{\pi}{2}$ & $\begin{array}{l}\text { The Feminist } \\
\text { Group Ottar } \\
\text { The } \\
\text { Norwegian } \\
\text { Association } \\
\text { for Women's } \\
\text { Rights }\end{array}$ & $\begin{array}{l}\text { Information and political work on women's eco- } \\
\text { nomic independence, violence against women, } \\
\text { reproductive rights, equality of heterosexual and } \\
\text { homosexual marriages, 'minority' women, sexual } \\
\text { liberation etc. } \\
\text { Participates in national debates and actions. Fo- } \\
\text { cus on sexual harassment and violence, reproduc- } \\
\text { tive rights, economic oppression, family politics, } \\
\text { lesbian/gay politics, international solidarity. Acti- } \\
\text { ve in battle against pornography and prostitution. } \\
\text { Dedicated to eliminating attitudes, laws and re- } \\
\text { gulations discriminatory towards women. Partici- } \\
\text { pates in public debates also at UN level. }\end{array}$ & $\begin{array}{l}\text { 'Majority' org. } \\
\text { 'Majority' org. }\end{array}$ \\
\hline 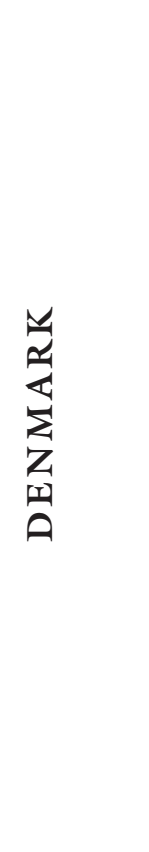 & $\begin{array}{l}\text { FAKTI - The } \\
\text { association of } \\
\text { women for } \\
\text { integration } \\
\text { Women s } \\
\text { Council } \\
\text { Denmark } \\
\text { 'The Globe' } \\
\text { House of } \\
\text { Volunteers } \\
\text { 'The meeting } \\
\text { place' }\end{array}$ & $\begin{array}{l}\text { Local neighbourhood org. started by Danish } \\
\text { women. Meeting place for women of various eth- } \\
\text { nic backgrounds, organizing social events and } \\
\text { teaching Danish language, society and culture. } \\
\text { National umbrella org. est. in 1899. Member of } \\
\text { EWL, access to policy-making bodies. In addition } \\
\text { to other women's issues, also focus on ethnic } \\
\text { 'minority' women. Has contributed to establish- } \\
\text { ing national umbrella 'minority' women's org. } \\
\text { Part of private housing estate in ethnically mixed } \\
\text { neighbourhood. Supports local initiatives, inclu- } \\
\text { ding an ethnic 'minority' women's org. } \\
\text { Autonomous institution organizing voluntary } \\
\text { work. Advise for all types of org., efforts to reach } \\
\text { ethnic 'minority' women. } \\
\text { Org. initiated and supported by local housing } \\
\text { estate. Intended as meeting place for all female } \\
\text { residents in area. Social activities. }\end{array}$ & $\begin{array}{l}\text { Cross-ethnic } \\
\text { 'Majority' org. } \\
\text { For all } \\
\text { residents } \\
\text { 'Majority' org. } \\
\text { Cross-ethnic }\end{array}$ \\
\hline
\end{tabular}

the Foreign Women's Group, established in 1979. Consistent with this conclusion, the Women's Council in Denmark on September 262009 invited minority women's organizations to partake in the founding gen- eral assembly for a new ethnic minority women's umbrella organization, a 'lived effect' appearing well into our work on this paper.

While Phillips laments that feminist schol- 
ars have become prone to paralysis by cultural difference, we hope to have emphasized that the question of paternalism versus paralysis is also relevant in considering the practices of women's organizations.

\section{Notes}

1. We use 'minority' and 'majority' in quotation marks, signifying dynamic and emergent processes of being and becoming (Gunaratnam 2003:19). However, to make the text more reader-friendly, we do not use quotation marks each time we use these concepts in the following.

2. The Norwegian study is part of FEMCIT:

'Gendered Citizenship in Multicultural Europe: The Impact of Contemporary Women's Movements' (see Halsaa et al. 2008).

3 . According to The Global Gender Gap Report 2008 by World Economic Forum, Norway ranks number 1 with the smallest gender gap and Denmark number 7 out of 130 countries.

4. For further evidence, see e.g. the policy documents from the Danish Ministry for Integration (2006 and 2009) and from Norway St. meld. Nr. 17 (1996-1997).

5. For further details see Halsaa et al. (2008).

6 . The concept 'women's movement' is used for a broad variety of women's organizing. The concept 'the feminist movement' is in this perspective seen as a subcategory of women's movements.

7. For further details see Pristed Nielsen (2008 and 2009).

8. See table for overview. We realize that majority organizations also include minority members.

9. See Chapter 7 in Halsaa et al. (2008) for further discussion of the institutional opportunity structures for women's organisations in Norway.

10. See Chapter 6A in Halsaa et al. (2008) for further discussion of minority and majority women's organisations in Norway in the 1970s and 80s.

11. It is debatable whether this is a subjectification effect or a matter of agency. Overall, Bacchi's approach leaves little room for analyses of agency, which is unfortunately not a discussion we can develop further here.

12. Thus, Siim and Skjeie "highlight differences in legal regulations and policy discourse" (2008:

324) when assessing the content of substantive policy making on gender equality, where a "minority group related gender equality agenda is developing" (2008: 323).

\section{LITERATURE}

- Bacchi, Carol Lee (1999): Women, Policy and Politics. The construction of policy problems. Sage Publications, London.

- Bacchi, Carol Lee (2009): Analysing Policy: What's the problem represented to be? Pearson Education, French Forest, New South Wales.

- Bredal, Anja (2007): Den 'spesielle volden'. Vold mot minoritetsjenter på sidelinjen, in: Knut Storberget et al. (eds.): Bjornen sover. Om vold i familien. Aschehoug, Oslo.

- Danish Ministry for Integration (2009): Nydanske kvinders ressourcer i fokus - syv kvindeinitiativer sattes $i$ gang, http://www.nyidanmark.dk/NR/rdonlyres/3FBBAB8E-D87D-48BE-A6E7-

6B091D1DBB4F/0/kvindeprogrammet_programbeskrivelse_feb_09.pdf

- Danish Ministry for Integration (2006): Declaration on integration and active citizenship in Danish society, http://www.nyidanmark.dk/NR/rdonlyres/7A32FAD0-E279-467C-91E3-

3074249ED586/0/integrationserklaering_engelsk.pdf

- Dogan, Mattei and Pelassy, Dominique (1990):

How to Compare Nations. Strategies in Comparative Politics. Chatham House Publishers, New Jersey.

- Eggebø, Helga, Halsaa, Beatrice, Skjeie, Hege and Thun, Cecilie (2007): Organisasjonslandskapet $i$ eit kjønnsperspektiv, 1990-2007. Senter for kvinneog kjønnsforskning, Universitetet i Oslo.

- Gunaratnam,Yasmin (2003): Researching 'Race' and Ethnicity. Methods, Knowledge and Power. Sage Publications, London.

- Halsaa, Beatrice, Thun, Cecilie and Predelli, Line Nyhagen (2008): Women's Movements: Constructions of Sisterhood, Dispute and Resonance: The Case of Norway. WP 4, Working Paper No.4, Centre for Gender Research, University of Oslo (http://www.femcit.org/publications.xpl) - Langvasbråten, Trude (2008): A Scandinavian Model? Gender Equality Discourses on Multiculturalism, in: Social Politics Spring 2008.

- Narayan, Uma (1997): Dislocating Cultures. Identities, Traditions, and Third World Feminism. Routledge, London and New York.

- Phillips, Anne (2007): Multiculturalism without Culture. Princeton University Press, Princeton. - Pristed Nielsen, Helene (2008): Etniske Minoritetskvinders Medborgerskab i Danmark, AMID Working Paper Series, 63/2008 (http://www.amid.dk/pub/papers/AMID_63_Pr isted.pdf)

- Pristed Nielsen, Helene (2009): Islam: a dead end for integration of female immigrants in Den- 
mark?, pp. 137-150 in: Vivienne Angeles \& Glenda Bonifacio (eds.): Gender, Religion and Migration: Pathways of Integration. Lexington Books, Maryland.

. Salimi, Fakhra (2004): Den historiske utviklingen av svarte og etniske minoriteters kvinnebevegelse: Noen av oss er modige, in: Mira-magasinets 10 års jubileumsnummer, 1-2.

- Siim, Birte and Skjeie, Hege (2008): Tracks, Intersections and Dead Ends. Multicultural challenges to state feminism in Denmark and Norway, in: Ethnicities 8(3).

. St. meld. Nr. 17 (1996-1997): Om innvandring og det flerkulturelle Norge. Kommunal- og arbeidsdepartementet.

http://www.regjeringen.no/nb/dep/krd/dok/re gpubl/stmeld/19961997/stmeld-nr-17-1996-

1997-.html?id=191037

- Strauss, Anselm and Corbin, Juliet (1998): Basics of Qualitative Research. Techniques and Procedures for Developing Grounded Theory. Sage Publications, London.

- World Economic Forum (2008): The Global Gender Gap Report,

http://www.weforum.org/pdf/gendergap/re-

port2008.pdf

\section{SUMMARY}

Inclusive women's organisations in Denmark and Norway?

The article demonstrates how majority women's organizations in Denmark and Norway react differently to the challenge of collaborating with new groups of women in society. The question of collaboration with minority women's organizations prompts existing majority organizations to navigate between a Scylla of paternalism and a Charybdis of paralysis. Based on interview data collected within majority women's organizations, the conclusion is that Norwegian organizations are relatively more prone to paralysis and Danish organizations relatively more prone to paternalism.

Helene Pristed Nielsen, post.doc.

FREIA Center for Gender Studies

Aalborg University

Cecilie Thun, PhD Candidate

Centre for Gender Studies

University of Oslo 